\title{
American Association for the Advancement of Science
}

\section{Virginia Meeting}

\begin{abstract}
THE American Association for the Advancement of Science meets in Richmond for its first Virginia convention on December 26-31.

On Monday evening, December 26, at the John Marshall Hotel, editors of all Virginia newspapers, members of the National Association of Science Writers, prominent officials of the State and of the American Association and others will be entertained at dinner by members of the local Virginia Section of the American Chemical Society planning com. mittee, headed by Lloyd C. Bird. Sir Richard Gregory, editor of NATURE, is to be the principal speaker. Austin H. Clark, curator of the Division of Echinoderms at the Smithsonian Institution and formerly director of the press service for the Association, will be honoured at this meeting for his long service and untiring co-operation with the Press of the world in helping to make available scientific news for the public.

Dr. George D. Birkhoff, professor of mathematies at Harvard University and retiring president of the Association, will be the principal speaker at a general session on Tuesday night at the Mosque. His subject will be "Intuition, Reason and Faith in Science". Dr. Wesley C. Mitchell, professor of economics at Columbia University and president of the Association, will preside. The address will be followed by a reception by the local committee to the Association and guests at the Thomas Jefferson Hotel.
\end{abstract}

The joint session of the Society of the Sigma Xi and the Association will be held on Wednesday night at the Mosque with Dr. W. F. Durand, emeritus professor of engineering at Stanford University, as the principal speaker. Dr. Durand is a past president of Sigma Xi, the leading honorary scientific fraternity of the United States and a member of the National Committee for Aeronautics. His subject for the seventeenth annual Sigma Xi lecture will be "Modern Trends in Air Transport".

On Thursday evening there will be a joint general session of the United Chapters of Phi Beta Kappa and the American Association at the Mosque. The lecturer will be Dr. Frank Pierrepont Graves, New
York State Commissioner of Education, and his subject will be "Is Education a Science?"

The mental health symposium, one of the features of the meeting, will end on Friday night with a general session at the Mosque. Dr. C. Macfie Campbell, professor of psychiatry at Harvard Medical School, will be the principal speaker.

As a contribution to the general public, members of the local planning committee are arranging a public meeting at the Mosque for either Saturday afternoon or evening with Dr. William M. Mann, director of the National Zoological Park, Washington, D.C., as the speaker. Dr. Mann has kindly consented to show and explain his motion pictures taken in Sumatra during an expedition for specimens for the National Zoo. This motion picture and Dr. Mann's address will be one of the principal features for the public during the meeting.

In order to commemorate the outstanding work of Virginia's first State geologist, W. B. Rogers, after whom Mount Rogers in Southwest Virginia is named, on the occasion of the Virginia meeting of the American Association, the Virginia Section of the American Chemical Society has organized a tour to include a visit to White Top and Mount Rogers in picturesque southwest Virginia. The erection of a tower of native rock on top of Mount Rogers, which would give visitors and pilgrims to this beauty spot a view of five States, is one of the proposals for the memorial. Prof. Rogers, a graduate of the College of William and Mary, where his father was a professor, was appointed professor of natural philosophy at the University of Virginia, and first State geologist in charge of the Virginia Geological Survey in 1835. His work brought him national recognition as a leading Virginia man of science, and created a general appreciation of that day of the scientific possibilities in Virginia. Dr. Rogers helped in the formation of the Association of American Geologists and Naturalists. He was elected president of the Association in 1848, when it was transformed into the American Association for the Advancement of Science, and in 1876 became president of the latter body.

\section{Laboratory of Saharan Biology}

\begin{abstract}
THE extent of investigations carried out by the 1 French in the Sahara is well known to the British scientific world, and not a fow British biologists have made that desert a field of their researches. In the past, such explorations have had to take the form of more or less arduous expeditions, which prevented more lasting observations requiring a convenient and suitably equipped base. The need of establishing such a base was recognized by French authorities some years ago, and all biologists interested in desert life will be glad to know of the existence of a Laboratory of Saharan Biology (Laboratoire de Biologie Saharienne) at Beni-Ounif, in the south of the Oran province of Algeria and on the border of French Morocco.
\end{abstract}

The Laboratory occupies an old fort, which was abandoned as it had lost its military importance, and comprises several rooms with the necessary furniture and scientific equipment. In a village which has grown around the fort one can obtain all the necessities of life, while its relatively small size enables one to reach unspoilt desert by a short walk. The environs of Beni-Ounif are exceptionally interesting for a biologist, since most of the types of desert environment can be found within easy distance: reg (hard, pebbly desert), hammada (stony desert), erg (sandhills), oueds (dry water-courses) and a large oasis with date cultivation. The Laboratory presents unique facilities, by its situation and equipment, for investigations on various problems of the ecology of 
desert plants and animals, which can be attacked by direct observation in the field combined with experiments on fresh material in the Laboratory.

Owing to insufficient publicity, the Laboratory has remained hitherto practically unknown to biologists outside France, and it is to be hoped that this note will attract the attention of biologists who may wish to work on desert biology, but believe that this must necessarily involve the discomforts of travelling and camping. Beni-Ounif is reached by train from Oran or Algiers in seventeen hours, and inexpensive accommodation can be found in one of the several local hotels. Foreign research students are very welcome, and no charge is made for the use of the Laboratory. Detailed information can be obtained from the director of the Laboratory, Prof. Ch. Killian, Faculté des Sciences, Algiers, Algeria.

B. P. Uvarov.

\section{University Events}

Cambridge.-In accordance with its usual practice, Trinity College announces the offer of a research studentship open to graduates of other universities who propose to go to Cambridge in October next as candidates for the degree of Ph.D. The value of the studentship may be as much as $£ 300$ a year. Candidates must not have reached the age of twenty-six years before May 1, 1939. In certain circumstances, an election may be made to an additional studentship. The same College offers, as usual, Dominion and Colonial exhibitions to students of Dominion and Colonial universities who wish to go to Cambridge next October as candidates for the degree of B.A., M.Litt., M.Sc., or Ph.D. These exhibitions are of the titular value of $£ 40$; but their actual value varies. Further particulars may be obtained from the Senior Tutor, Trinity College, Cambridge.

E. Rothbarth has been appointed assistant in statistical research.

The degree of master of arts has been conferred upon Dr. J. E. Driver (London), University demonstrator in chemistry.

At Emmanuel College, Dr. G. R. Owst, professor of education, has been elected into a professorial fellowship.

Prof. R. G. W. Norrish has been elected a member of the Council of the Senate.

London.-Dr. H. S. W. Massey, who has been since 1933 independent lecturer in mathematical physics in the Queen's University, Belfast, has been appointed as from January 1 to the Goldsmid chair of mathematics tenable at University College.

The Chester Beatty scholarship in radiology of the value of $£ 400$ for one year has been awarded to $\mathrm{Mr}$. E. P. Allen. This scholarship was established through the generosity of Mr. A. Chester Beatty for two years to enable students to study radiology in the United States.

The John Marshall fellowship of the value of $£ 500$ a year for two years has been awarded to Mr. K. C. Eden. This fellowship was established under the will of the late Miss A. B. Marshall in memory of her father, Prof. John Marshall.

The following doctorates have been conferred: D.Se. in biochemistry on J. F. Danielli ; D.Sc. in botany on Miss Ann C. Halket; D.Se. (engineering) on Prof. J. T. MacGregor-Morris.

\section{Science News a Century Ago}

Royal Astronomical Society

ON November 5, 1838, at a meeting of the Royal Astronomical Society, a letter written on October 23 from Königsberg by Bessel to Sir John Herschel was read, describing his efforts to determine the parallax of a fixed star. Bessel began his letter : "Esteemed Sir,-Having succeeded in obtaining a long-looked-for result, and presuming that it will interest so great and zealous an explorer of the heavens as yourself, I take the liberty of making a communication to you thereupon. Should you consider the communication of sufficient importance to lay before the other friends of astronomy, I not only have no objection, but request you to do so. With this view, I might have sent to you through Mr. Baily; and I should have preferred this course, as it would have interfered less with the important affairs claiming your immediate attention on your return to England. But, to you, I can write in my own language, and thus secure my meaning from indistinctness.'

Bessel then went on to deseribe how, to attempt the determination of the parallax of a star, he thought of using Fraunhofer's heliometer, why he chose 61 Cygni, and the course of his observations which were begun in September 1824. After having his heliometer repaired, he resumed the inquiry and in March 1840 terminated a series of 402 measures.

\section{Botanical Society of Edinburgh}

Aт a meeting of the Botanical Society of Edinburgh on November 8, 1838, Prof. Graham read an account of a visit which he, along with some friends, had paid to the west of Ireland in August, to examine its botanical productions. It was stated that the mountains of Cunna mara (sic) present very little of the alpine vegetation with which the mountains of Scotland are clothed, a difference probably arising from their structure; the summits, or nearly two thirds of their height being composed of the most unproductive quartz. Near the base of the mountains some micaceous soil exists, and there a little alpine vegetation was found. The only peculiarity which the quartz presented was abundance of Saxifraga umbrosa (athenceum).

Prof. Robert Graham was born at Stirling on December 7, 1786, and died at Coldoch in Perthshire on August 7, 1845. After practising medicine in Glasgow, he was appointed professor of botany in the University of Glasgow in 1818, being the first occupant of the chair. Two years later he was transferred to the chair of botany at Edinburgh, which he held until his death.

\section{The Australian Museum}

"Ir would not be easy to imagine", said the Mechanics' Magazine of November 10, 1838, "a more gratifying evidence of a young colony's progress in civilization than that which is given by a handsome volume, a few copies of which have lately reached this country. The book is 'A Catalogue of the Specimens of Natural History and Miscellaneous Curiosities deposited in the Australian Museum'. It is very handsomely printed 'by James Tegg and Co., at the Atlas Office, George-street Sydney', an offshoot from the well-known 'Thomas Tegg, at the Old Mansion House, Cheapside, London'," 